\title{
Preparation and Fire Test of Intumescent Powder Coatings
}

\author{
Heinrich Horacek \\ Free Consultance, A-4048 Puchenau, Am Wiesenrain 1, Puchenau, Austria \\ Email: heinrich.horacek@aon.at
}

Received 1 June 2014; revised 2 July 2014; accepted 15 July 2014

Copyright (C) 2014 by author and OALib.

This work is licensed under the Creative Commons Attribution International License (CC BY). http://creativecommons.org/licenses/by/4.0/

(c) (i) Open Access

\begin{abstract}
New regulations for hazardous air pollutants drove operations to compliant coatings. Powder coatings were the most popular choice. A screening of intumescent powder coatings was carried out comprising binders like thermoplastics as plasticised polyvinylchloride and polypropylene as well as non-cross linked thermosets as polyurethanes. Intumescence was achieved by addition of the intumescent ingredient bicyclopentaerythritol phosphate, by the intumescent combination polyethylene glycol as binder with ammonium polyphosphate and binders comprising intumescent phosphororganic polyesters. The intumescent ingredients and components were characterized by thermogravimetric analysis and described by chemical formulas together with their balances of weights and heats of formation. The electrically loaded powders were sprayed on grounded steel panels and subdued a fire test. The time, until the coated panels reached $500^{\circ} \mathrm{C}$, was observed. The panels coated with the plasticised polyvinylchloride plus bicyclopentaerythritol phosphate and those protected by the polyurethane comprising polyethylene glycol and ammonium polyphosphate delayed the period of time, until $500^{\circ} \mathrm{C}$ were reached, significantly and were equal in efficiency with the reference, the commercial water borne intumescent varnish.
\end{abstract}

\section{Keywords}

Intumescence, Powder Coating, Fire Test

Subject Areas: High Polymer Chemistry, Physical Chemistry, Thermochemistry

\section{Introduction}

The National Emission Standards for Hazardous Air Pollutions address low level of volatile organic compounds, reduction or elimination of certain hazardous alkyl phenols [1]. They drive operations to compliant coatings as powder, electro, autophoretic, UV, high solid and water borne coatings. Recently powder coating has been the most popular choice [2] [3]. Water borne and solvent based intumescent varnishes are a growing market. Espe- 
cially steel constructions are protected by intumescent coatings in order to enlarge the time lag, until $500^{\circ} \mathrm{C}$ are reached in the case of fire. At the temperature of $500^{\circ} \mathrm{C}$ steel looses $50 \%$ of its strength and stiffness.

Until now there are no intumescent powder coatings available on the market. In literature only patents [4]-[8] treat the subject. Several companies provide the market with heat resistant powder coatings, which consist of silicone, such as Alesta HR from Du Pont, or polyester resins, such as Pyrotect FR from DGL international Camel and they are highly filled with mica, wollastonite or other minerals [9]. They are applied in film thicknesses between 35 and $100 \mu \mathrm{m}$. The film thicknesses of powder coatings are limited with $0.5 \mathrm{~mm}$ for cold items and with $2.5 \mathrm{~mm}$ for hot parts. By definition water borne intumescent paints use water as solvent in solutions or as dispersant in dispersions [10]. They are sensitive to dirt and oil, which tend to create blisters and lead to poor adhesion and accelerated corrosion, nevertheless high solid and water borne coatings are replacing solvent based paints at an increasing rate. Metals generally require a minimum of 5 - 6 stages and separate cleaning and conversion stages. Plastics generally use a minimum of 6 - 8 stages. The most typical types of applications are dip, flow coat and spray. Electro and autophoretic coatings are dip processes by design, although dipping can be used to apply waterborne and powder coatings but is not practicable for high solids. Spray is the most common method of paint application, including air spray, air assisted airless, airless, HVLP (high volume low pressure) and electrostatic spray. HVLP benefits the environment by reducing the amount of bounce back of paint resulting in an improved transfer efficiency and lower paint usage. A schematic diagram of the electrostatic powder spray system is represented in Figure 1.

The yield of powder coatings is determined by the film thickness and the density of the film after curing in Equation (1).

$$
\text { Yield }\left(\mathrm{m}^{2} / \mathrm{kg}\right)=1000 /\left[\text { density }\left(\mathrm{g} / \mathrm{cm}^{3}\right) \times \text { thickness }(\mu \mathrm{m})\right]
$$

The expected costs are given by the price of the powder coating $€ / \mathrm{kg}$ divided by the yield in Equation (2).

$$
\text { Costs }\left(€ / \mathrm{m}^{2}\right]=\text { price }(€ / \mathrm{kg}) / \text { yield }\left(\mathrm{m}^{2} / \mathrm{kg}\right)=\text { price } \times \text { density } \times \text { thickness } / 1000
$$

The costs are driven by price, density and film thickness after curing.

Today ovens for the curing or melting of powder coatings are available even for parts as large as $7 \mathrm{~m}$ length and as heavy as 5 tons [11]. Figure 2 demonstrates the large dimensions of a curing oven showing the small labourer in comparison with the huge oven.

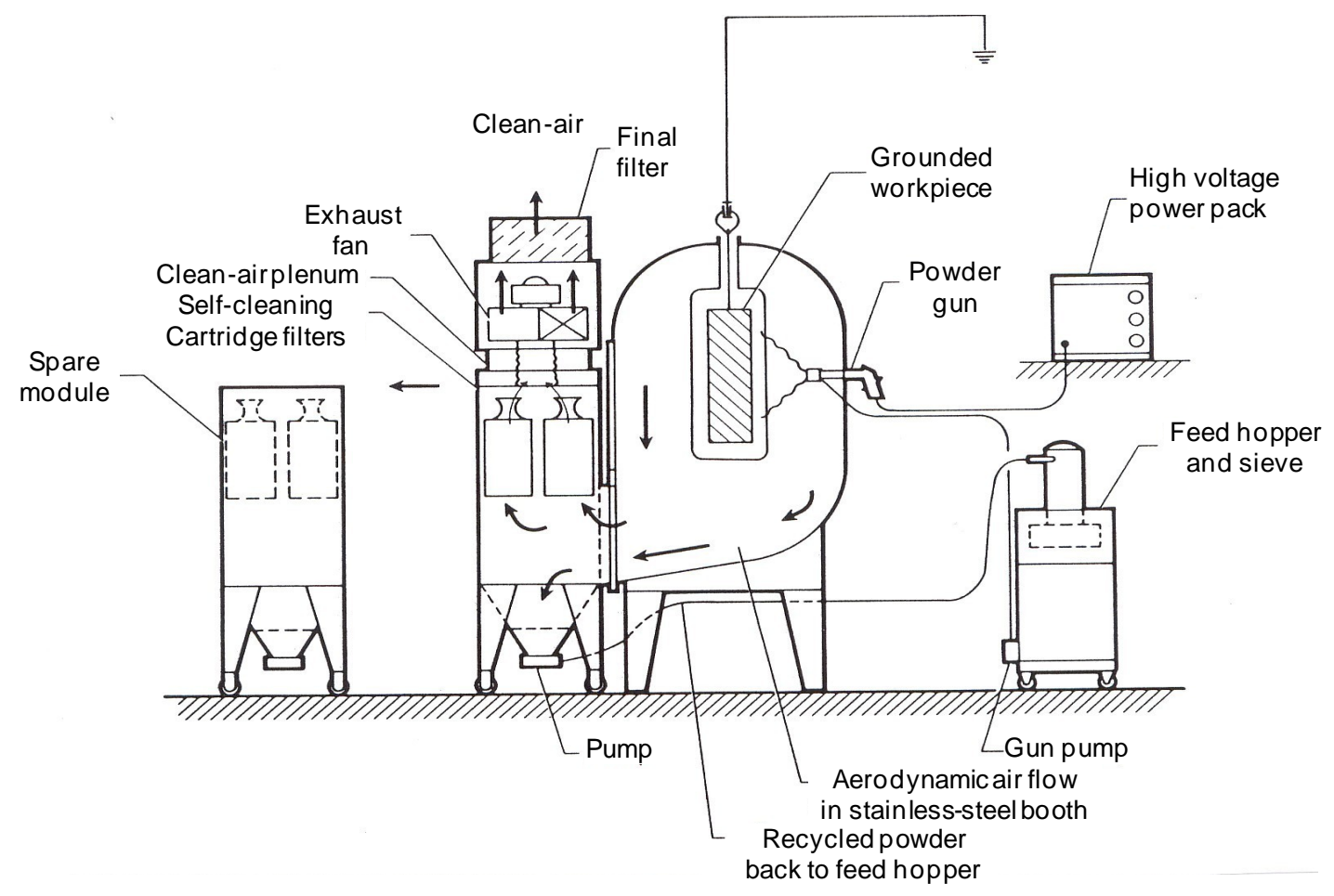

Figure 1. Schematic diagram of electrostatic powder spray system [2]. 


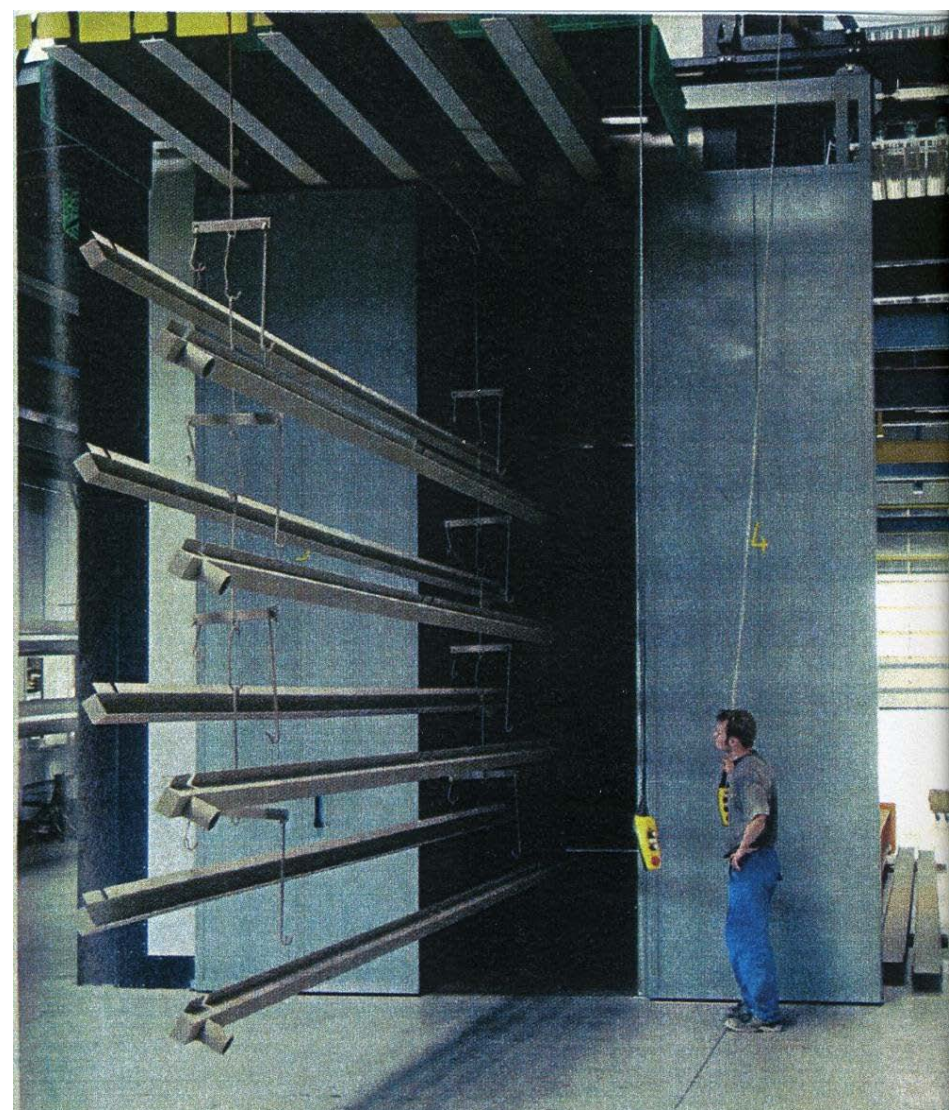

Figure 2. Dimensions of ovens available for curing and sintering of powder coatings [11].

In order to obtain a general view over the whole scope of intumescent powder coatings, seven recipies are developed: two formulations based on thermoplastic binders, namely plastisized polyvinylchloride PPVC and polypropylene PP comprising bicyclopentaerythritol phosphate as intumescent ingredient. PPVC is chosen for char formation and low combustion. PP is selected, because it can be degraded to well flowing low molecular products by the addition of peroxides. Five non-cross linked thermosets comprising uretdione and linear polyesters as well as polyethylene glycol react to polyurethanes. Bicyclopentaerythritol phosphate is added as intumescent ingredient in the cases, when the binders show no intumescence by themselves. Use is made of the intumescent phosphororganic polyesters as binding component as well as intumescent mixtures of polyethylene glycol and ammonium polyphosphate. Polyurethanes are very familiar in powder coatings, for instance, Vestagon from Evonik and Crelan from Bayer are well known commercial products.

In principle, powder coatings are manufactured by dry blending or by melt mixing processes, which is described as flow diagram in Figure 3.

The milled powders and the water borne commercial paint Nonfire S168 are applied to steel panels and subdued a fire test.

\section{Experimental}

\subsection{Materials}

In Table 1 all chemicals and products used as well as their suppliers were listed.

\subsection{Methods}

The intumescent ingredients were characterized by thermal gravimetric analysis (TGA) on a Mettler Toledo TMA/SDTA with TGA/SDTA 851 Modul. The samples were placed in aluminium oxide crucibles of $900 \mu \mathrm{l}$ 

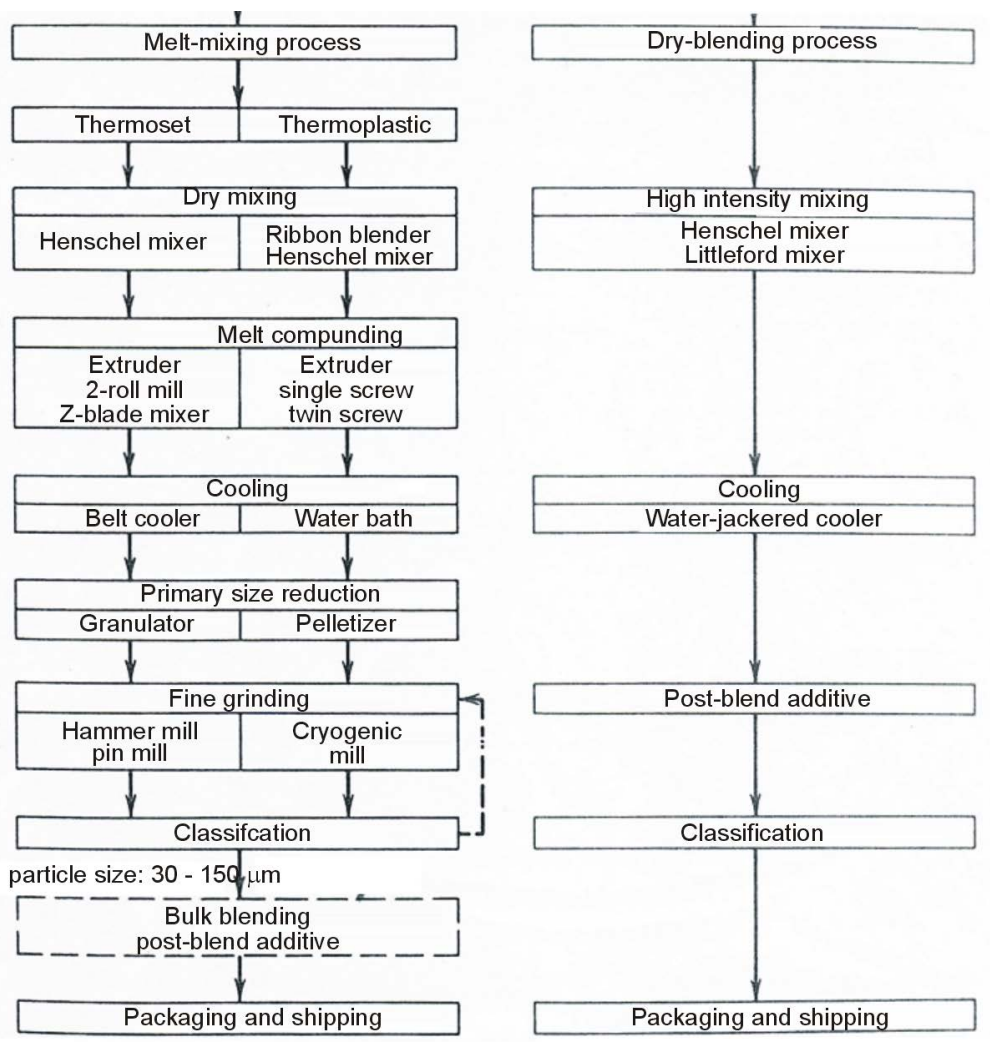

Figure 3. Flow diagram of powder coating manufacturing [2].

Table 1. Chemicals, brand names, abbreviations, formulas, suppliers.

\begin{tabular}{|c|c|c|c|c|}
\hline Chemical & Brand name & Abbreviation & Formula & Supplier \\
\hline Ammonium polyphosphate & Exolit 422 & APP & $\mathrm{NH}_{4} \mathrm{PO}_{3}$ & Clariant \\
\hline Titanium oxide & Kronos 2300 & $\mathrm{TiO}_{2}$ & $\mathrm{TiO}_{2}$ & Kronos \\
\hline Bicyclopentaerythritol phosphate & NH-1197 & ВСРР & $\mathrm{C}_{5} \mathrm{H}_{9} \mathrm{PO}_{5}$ & Great Lakes \\
\hline Plastisized Polyvinylchloride & Rottolin 02535 & PPVC & $\mathrm{CH}_{2} \mathrm{CHCl}$ & Rottolin \\
\hline Polypropylene & US 10 & PP & $\mathrm{CH}_{2}-\mathrm{CHCH}_{3}$ & Borealis \\
\hline 2,5 Bis(ter.Butyldimethyldioxo)hexane & Interox DH BP451C & Peroxide & $\mathrm{C}_{16} \mathrm{H}_{34} \mathrm{O}_{4}$ & Interox \\
\hline Polyethylene wax & Hostalub & & $\mathrm{CH}_{2}-\mathrm{CH}_{2}$ & Hoechst \\
\hline Calcium stearate & & Castearate & $\mathrm{Ca}\left(\mathrm{C}_{17} \mathrm{H}_{35} \mathrm{CO}_{2}\right)_{2}$ & Dr.L.C.Marquart GmbH \\
\hline Montan Wax & & Montan & $\mathrm{C}_{26}-\mathrm{C}_{32}$ & BASF \\
\hline Isophorondiisocyanate uretdione & Crelan LS 2147 & Uretdione & $\mathrm{C}_{12} \mathrm{H}_{19} \mathrm{~N}_{2} \mathrm{O}_{2}$ & Bayer \\
\hline Polyethylene glycol & Pluriol E1500 & PEG & $\mathrm{CH}_{2}-\mathrm{CH}_{2}-\mathrm{O}$ & BASF \\
\hline Tin octoate & & Snoctoate & $\mathrm{Sn}\left(\mathrm{O}_{2} \mathrm{C}-\left(\mathrm{CH}_{2}\right)_{6} \mathrm{CH}_{3}\right)_{2}$ & Bärlocher \\
\hline Diazabicyclooctane & DABCO & Dabco & $\mathrm{C}_{6} \mathrm{H}_{12} \mathrm{~N}_{2}$ & Bayer \\
\hline Aluminium silicate & Zeolithe P & Zeolithe & $\mathrm{Na}, \mathrm{Ca}\left[\mathrm{Al}_{2} \mathrm{Si}_{4} \mathrm{O}_{12}\right] \times \mathrm{H}_{2} \mathrm{O}$ & Bayer \\
\hline Dibutyltindilaurate & DBTDL & DBTDL & $\left(\mathrm{C}_{4} \mathrm{H}_{9}\right)_{2} \mathrm{Sn}\left(\mathrm{C}_{11} \mathrm{H}_{23} \mathrm{CO}_{2}\right)_{2}$ & Bärlocher \\
\hline Succinic acid & & & $\mathrm{HOOCCH}_{2} \mathrm{COOH}$ & DSM \\
\hline 1,4 Butanediol & & & $\mathrm{OH}\left(\mathrm{CH}_{2}\right)_{4} \mathrm{OH}$ & BASF \\
\hline Diethylene glycol & DEG & & $\mathrm{OH}\left(\mathrm{CH}_{2}\right)_{2} \mathrm{O}\left(\mathrm{CH}_{2}\right)_{2} \mathrm{OH}$ & Hoechst \\
\hline Triethylamine & & & $\left(\mathrm{C}_{2} \mathrm{H}_{5}\right)_{3} \mathrm{~N}$ & BASF \\
\hline $\begin{array}{l}\text { N,Ndihydroxyethylmethylaminediethyl- } \\
\text { phosphonate }\end{array}$ & Levagard N4090 & & $\mathrm{C}_{9} \mathrm{H}_{22} \mathrm{NO}_{5} \mathrm{P}$ & Clariant \\
\hline Maleic anhydride & & MSA & $\mathrm{C}_{4} \mathrm{H}_{2} \mathrm{O}_{3}$ & DSM \\
\hline p-Toluene sulfonic acid & & TS & $\mathrm{C}_{7} \mathrm{H}_{7} \mathrm{SO}_{3} \mathrm{H}$ & Fluka \\
\hline Silicone oil & DC 193 & Silicone & $\left(\mathrm{CH}_{3}\right)_{2}-\mathrm{Si}-\mathrm{O}$ & Dow Corning \\
\hline Water borne intumescent paint & Nonfire S168 & & & Tikkurila Comp. \\
\hline
\end{tabular}


volume (ME 511119, 960) with $12 \mathrm{~mm}$ diameter covered by punctured lids. The TGA measurements took place under nitrogen with $80 \mathrm{ml} / \mathrm{min}$ at a heating rate of $5 \mathrm{~K} / \mathrm{min}$. The TMA measurements were performed in aluminium oxide crucibles with $7 \mathrm{~mm}$ diameter and $4.6 \mathrm{~mm}$ height covered by $6 \mathrm{~mm}$ diameter lids in air at a heating rate of $50 \mathrm{~K} / \mathrm{min}$ under nitrogen.

All formulations were made by the dry blending process.

The powdery ingredients of intumescent powder coatings were mixed in a high speed Henschel impeller mixer. The mixtures were cooled in water jacketed cooler. Under cooling the mixtures were ground on a Baumeister pin mill and classified by sieving. The particle sizes of the ground mixtures were determined with Master Sizer XSB.OD from Malvern Instruments.

The melt viscosities of the thermoplastic powders were measured on a Rheograph 2000 (Göttfert) at low shear forces $230 \mathrm{sec}^{-1}$ according to DIN 54811. The curing of the thermosets was investigated on a Plasticorder (Göttfert). The measurement started at a product temperature of $100^{\circ} \mathrm{C}$ and stopped at $200^{\circ} \mathrm{C}$ after 20 minutes at a constant heating rate of $5 \mathrm{~K} / \mathrm{min}$.

A Wagner powder spraying device with a PEM-C3 spray gun, a steering device EPG 2007 and a powder injector PJ 2020 PRS was used for the process of spraying. The powders were blown through a voltage field of 50 $\mathrm{kV}$. Small steel boards with the dimensions $25 \times 25 \times 0.5 \mathrm{~cm}^{3}$ were the objects of spraying, which were equipped with two iron Constantan thermocouples.

The film thickness was measured by the inductive method with MiniTest 7.400 (Elektrophysik).

Curing and melting was performed in a small oven at temperatures between $160^{\circ} \mathrm{C}-250^{\circ} \mathrm{C}$ and times of 10 15 minutes.

The fire tests were performed in a $1 \times 1 \times 1 \mathrm{~m}^{3}$ furnace from company Riedhammer.

The panels were placed between two $20 \mathrm{~mm}$ silicate boards of Promatect $\mathrm{H}$. The board looking to the furnace had 9 windows: one for the naked panel, one for the reference sample and the seven left for the panels coated with the powder coatings. The whole arrangement was placed at the front of the furnace, which was heated according to the ISO curve.

The decomposition of intumescent components was described with chemical formulas $\mathrm{F}$, complete balances of weights MW (g/mole) and heats of formation $\mathrm{H}(\mathrm{kJ} / \mathrm{mole})$. The formulas and the weight balance had to be in agreement with the weight residues $\mathrm{R}$ determined by thermogravimetric measurements. In the following the method was exemplified on the example ammonium polyphosphate $\mathrm{NH}_{4} \mathrm{PO}_{3}$ :

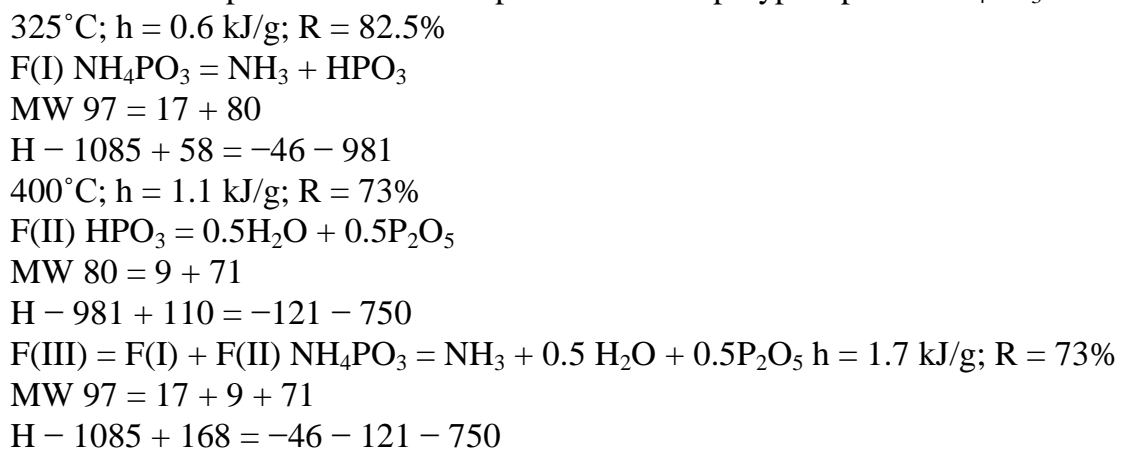

\section{Results}

\subsection{Synthesis of Linear Polyesters}

\subsubsection{Succinic Acid 1,4 Butanediol Polyester (1)}

A $1000 \mathrm{ml}$ three necked round bottom flask equipped with mechanical stirrer, reflux condenser, thermometer, addition funnel and dry nitrogen inert was loaded with $161.2 \mathrm{~g}(1.5 \mathrm{~m})$ succinic acid and $135 \mathrm{~g}(1.5 \mathrm{~m}) 1.4 \mathrm{bu}-$ tanediol. Under nitrogen $3 \mathrm{~g}$ of p-toluene sulphonate were added. The temperature was raised to $200^{\circ} \mathrm{C}$ and kept for $3 \mathrm{~h}$. Then the nitrogen supply was stopped and vacuum was applied. Heating at $200^{\circ} \mathrm{C}$ was continued for further $5 \mathrm{~h}$. The solid polyester melted at $68^{\circ} \mathrm{C}$ and showed an hydroxyl number of 56 and acid number of 4.8.

\subsubsection{Pentaerythritol Diphosphite Diethylene Glycol Polyester (2) and of Pentaerythritol Diphosphate Diethylene glycol Polyester (3)}

A $2000 \mathrm{ml}$ three necked round bottom flask was equipped with a mechanical stirrer, reflux condenser, ther- 
mometer, addition funnel and dry nitrogen inert.

In case (2) a solution of $0.5 \mathrm{~mol}$ (132.5 g) dichloropentaerythritoldiphosphite [12] in $500 \mathrm{~g}$ toluene and in case (3) a solution of $0.5 \mathrm{~mol}$ (148.5 g) dichloropentaerythritoldiphosphate [13] in $500 \mathrm{~g}$ toluene were added over a period of $1 \mathrm{~h}$ to a solution of $0.53 \mathrm{~m}$ (56.2 g) diethylene glycol (Hoechst) and 101 (1 mol) triethylamine (BASF) in $800 \mathrm{~g}$ toluene. Both solutions were heated at reflux for $5 \mathrm{~h}$. The precipitated triethyl amine hydrochloride was filtered. The filtrates were concentrated by heating to a final temperature of $160^{\circ} \mathrm{C} / 5 \mathrm{~mm}$ vapour pressure. The solid final products were characterized:

Polyester (2) Melting point $\mathrm{Tm}=90^{\circ} \mathrm{C}$, elementary analysis: $37.2 \% \mathrm{C}, 5.8 \% \mathrm{H}, 18.6 \% \mathrm{P}$

Acid number (DIN 53240): 2, hydroxyl number (DIN 53402): 112

Polyester (3) Melting point $\mathrm{Tm}=80^{\circ} \mathrm{C}$, elementary analysis $34.5 \% \mathrm{C}, 5.5 \% \mathrm{H}, 16.2 \% \mathrm{P}$

Acid number: 150, hydroxyl number: 1050

The high hydroxyl number indicated hydrolysis of polyester (3) in the presence of watery bases during titration, when the hydroxyl number was determined.

\subsubsection{N, N Dihydroxyethylmethylamine Diethylphosphonate Fumaric Acid Polyester (4)}

The equipment was used as already mentioned. The $1000 \mathrm{ml}$ flask was loaded with $1.1 \mathrm{~mol}$ (280 g) dihydroxyethylmethylamine diethylphosphonate, Levagard $4090 \mathrm{~N}$ (Clariant). Through a powder funnel $1 \mathrm{~mol}$ (98.1 g) maleic anhydride (DSM fine Chemicals) was added. The temperature was raised to $60^{\circ} \mathrm{C}$. When the solution was clear, the temperature was raised until reflux occurred. The mixture was stirred at reflux for $6 \mathrm{~h}$. $19 \mathrm{~g}$ water was removed under vacuum. After cooling the low molecular impurities were removed by solving in benzene and precipitating in petrol ether. The solid residue was characterized:

Melting temperature $\mathrm{Tm}=95^{\circ} \mathrm{C}$, elementary analysis: $45.7 \% \mathrm{C}, 7.0 \% \mathrm{H}, 4.4 \% \mathrm{~N}, 9.8 \% \mathrm{P}$

Acid number: 18, hydroxyl number: 90.

In Figure 4 the synthesized linear polyesters were described by chemical formulas.

\subsection{Characterization of Intumescent Addives and Components}

In Figure 5 the residues by weight R of bicyclopentaerythritol phosphate BCPP and of the mixture polyethylene glycol PEG and ammonium polyphosphate APP 1:1 parts by weight were determined in dependence of temperature. BCPP exerted intumescence at $350^{\circ} \mathrm{C}$ and the mixture polyethylene glycol and ammonium polyphosphate at $275^{\circ} \mathrm{C}$.

TMA measurements failed, because the produced foams were not stable enough. Intumescence was followed visually.

Formulas and their balances of molar weights and heats of formation were set up, which described the loss of weights measured by TGA.

BCPP Bicyclopentaerythritol phosphate $\mathrm{C}_{5} \mathrm{H}_{9} \mathrm{PO}_{5}$ :

$340^{\circ} \mathrm{C} \mathrm{h}=-0.26 \mathrm{~kJ} / \mathrm{g} ; \mathrm{R}=80 \%$

F1: $\mathrm{C}_{5} \mathrm{H}_{9} \mathrm{PO}_{5}=\mathrm{C}_{5} \mathrm{H}_{4} \cdot \mathrm{HPO}_{3}+2 \mathrm{H}_{2} \mathrm{O}$
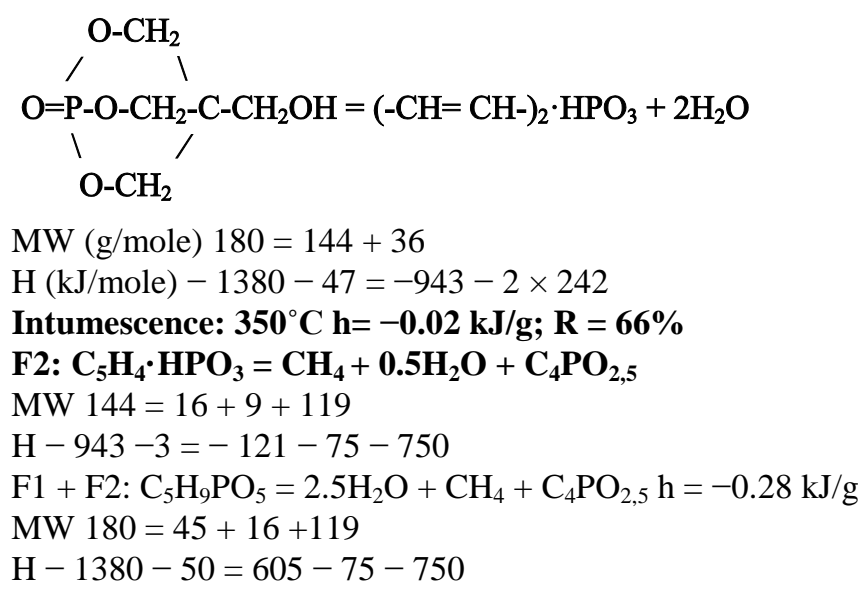

PEG Polyethylene glycol—APP Ammonium polyphosphate 1/1 by weight $=76 \% 1 \mathrm{~m} \mathrm{EG} / 1 \mathrm{~m}$ APP and $24 \%$ EG in excess: 


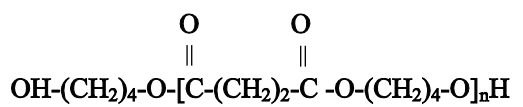

(1)

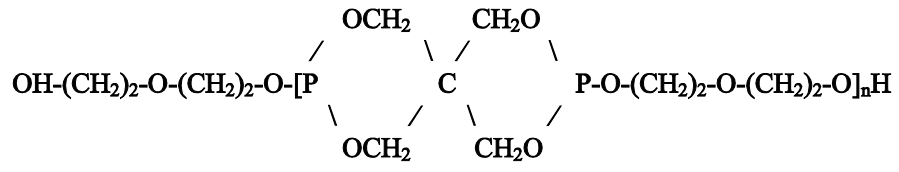

(2)

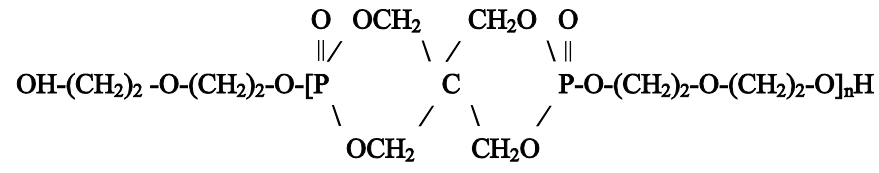

(3)

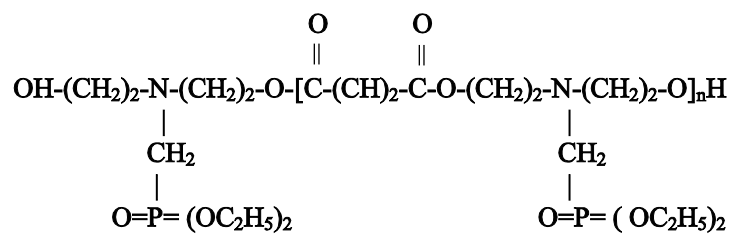

(4)

Figure 4. Linear Polyesters: Succinic acid 1,4 Butanediol (1), Pentaerythritoldiphosphite diethylene glycol (2), Pentaerythritoldiphosphate diethylene glycol (3), N,N Dihydroxyethylmethylamine diethylphosphate fumaric acid (4).

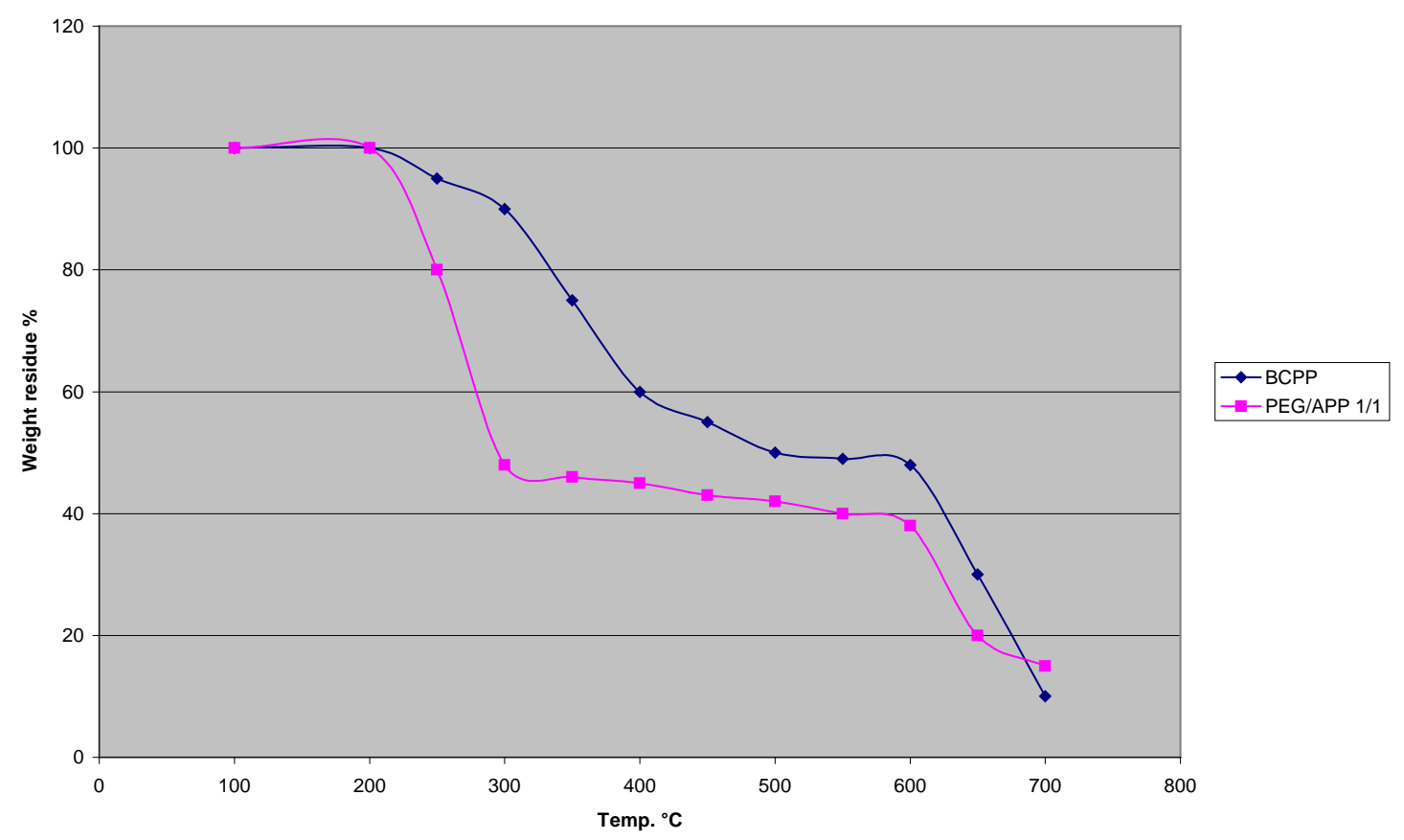

Figure 5. TGA of the intumescent additives BCPP and PEG/APP = 1/1 by weight, air, $5 \mathrm{~K} / \mathrm{min}$. 
$250^{\circ} \mathrm{C} \mathrm{h}=0.76 \times 0.69=0.52 \mathrm{~kJ} / \mathrm{g} ; \mathrm{R}=100-0.76 \times(100-88)=91 \%$

F3: $\left(-\mathrm{CH}_{2}-\mathrm{CH}_{2} \mathrm{O}-\right) \mathrm{n}+\mathrm{nNH}_{4} \mathrm{PO}_{3}=\mathrm{n}\left(-\mathrm{CH}_{2}-\mathrm{O}-\right)_{2} \mathrm{POHO}+\mathrm{nNH}_{3}$ (cyclo Ethylene phosphate)

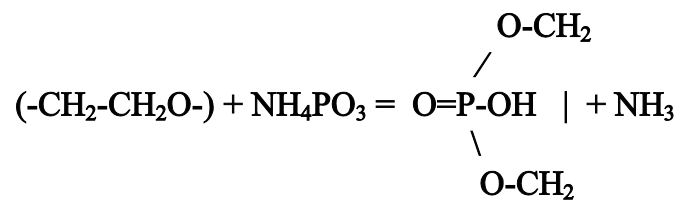

MW $44+97=124+17$

$\mathrm{H}-200-1085+97.5=-1141.5-46$

$250^{\circ} \mathrm{C} \mathrm{h}=0.76^{*}-0.04=-0.03 \mathrm{~kJ} / \mathrm{g} ; \mathrm{R}=100-0.76 \times(100-75)=81 \%$

F4: $\left(-\mathrm{CH}_{2}-\mathrm{O}-\right)_{2} \mathrm{POHO}=\mathrm{C}_{2} \mathrm{H}_{2} \cdot \mathrm{HPO}_{3}+\mathrm{H}_{2} \mathrm{O}$

MW $124=106+18$

$\mathrm{H}-1141.5-6=-905.5-242$

Intumescence: $275^{\circ} \mathrm{C} \mathrm{h}=0.76 *-0.02=-0.015 \mathrm{~kJ} / \mathrm{g} ; \mathrm{R}=0.76 \times 63 \%=48 \%$

F5a: $\mathrm{C}_{2} \mathrm{H}_{2} \cdot \mathrm{HPO}_{3}=0.5 \mathrm{CH}_{4}+0.5 \mathrm{H}_{2} \mathrm{O}+\mathrm{C}_{1,5} \cdot \mathrm{PO}_{2,5}$

MW $106=8+89+9$

$\mathrm{H}-905.5-3=-37.5-121-750$

$300^{\circ} \mathrm{C}: \mathrm{h}=0.24 \times 3.39=0.81 \mathrm{~kJ} / \mathrm{g} ; \mathrm{R}=0 \%$

F5b: $\left(-\mathrm{CH}_{2}-\mathrm{CH}_{2} \mathrm{O}-\right)=-\mathrm{CH}_{2}-\mathrm{CH}_{2} \mathrm{O}$-gas

MW $44=44$

$\mathrm{H}-200+149=-51$

$\mathrm{F} 3+\mathrm{F} 4+\mathrm{F} 5 \mathrm{a}: \mathrm{C}_{2} \mathrm{H}_{4} \mathrm{O}+\mathrm{NH}_{4} \mathrm{PO}_{3}=\mathrm{C}_{1,5} \mathrm{PO}_{2,5}+1.5 \mathrm{H}_{2} \mathrm{O}+\mathrm{NH}_{3}+0.5 \mathrm{CH}_{4} \mathrm{~h}=0.76 \times 0.63=0.47 \mathrm{~kJ} / \mathrm{g} ; \mathrm{R}=0.76$

$\times 63=48 \%$

$\mathrm{MW} 44+97=89+27+17+8$

$\mathrm{H}-200-1085+88.5=-750-363-46-37.5$

The PEG/APP mixture 1:1 degraded under heat uptake of $0.52-0.03-0.015+0.47=0.945 \mathrm{~kJ} / \mathrm{g}$. Intumescence was observed at $275^{\circ} \mathrm{C}$. BCCP expanded by intumescence under heat evolution of $-0.28 \mathrm{~kJ} / \mathrm{g}$ at $350^{\circ} \mathrm{C}$.

By the same method the linear polyesters were investigated.

In Figure 6 the synthesized polyesters were subjected to thermogravimetric analysis (TGA).

All polyesters degraded in the range of $250^{\circ} \mathrm{C}-700^{\circ} \mathrm{C}$. The succinic-polyester (1) degraded at $300^{\circ} \mathrm{C}$ without intumescence. The phosphite-polyester (2) decomposed under intumescence at $350^{\circ} \mathrm{C}$. The phosphate-polyester (3) showed the highest degree of intumescence at the same temperature. The phosphonite-polyester (4) exerted no intumescent behaviour. The expansion was estimated by visual examination, the exact measurement was tried by TMA investigation but failed, because the foams were not stable enough and collapsed. In the following degradation and intumescence were described by the balance of heats of formation and weights.

Succinic-polyester (1) with the repetition unite $\mathrm{C}_{8} \mathrm{H}_{12} \mathrm{O}_{4}(\mathrm{MW}=172 \mathrm{~g} / \mathrm{mole}) ; \mathrm{R}_{500}{ }^{\circ} \mathrm{C}=0 \% ; \mathrm{h}=0.3 \mathrm{~kJ} / \mathrm{g}$

$350^{\circ} \mathrm{C}: \mathrm{h}=0.3 \mathrm{~kJ} / \mathrm{g}, \mathrm{R}=0 \%$

F7: $\mathrm{C}_{8} \mathrm{H}_{12} \mathrm{O}_{4}=2 \mathrm{CO}_{2}+3 \mathrm{C}_{2} \mathrm{H}_{4}$

MW $172=88+84$

$\mathrm{H}-681+51=-786+3 \times 52$

Phosphite-polyester (2) with the repetition unite $\mathrm{C}_{9} \mathrm{H}_{16} \mathrm{O}_{7} \mathbf{P}_{2}(\mathrm{MW}=298 \mathrm{~g} / \mathrm{mole}) ; \mathbf{R}_{500}{ }^{\circ} \mathrm{C}=35 \% ; \mathbf{h}=-0.28$ $\mathbf{k J} / \mathbf{g}$

$250^{\circ} \mathrm{C}: \mathrm{h}=-0.5 \mathrm{~kJ} / \mathrm{g} ; \mathrm{R}=100 \%$

F8: $\mathrm{C}_{9} \mathrm{H}_{16} \mathrm{O}_{7} \mathrm{P}_{2}=\mathrm{C}_{5} \mathrm{H}_{9} \mathrm{PO}_{5}+\mathrm{C}_{4} \mathrm{H}_{7} \mathrm{PO}_{2}$

$\mathrm{CH}_{2}-\mathrm{CH}$

I

$\mathrm{C}_{9} \mathrm{H}_{16} \mathrm{O}_{7} \mathrm{P}_{2}=\mathrm{BCPP}+\mathrm{O}-\mathrm{P}-\mathrm{OH} \|$

MW $298=180+118$

$\mathrm{H}-2113+149=-1380-584$

$300^{\circ} \mathrm{C}: \mathrm{h}=-0.04 \mathrm{~kJ} / \mathrm{g} ; \mathrm{R}=71.8 \%$ 


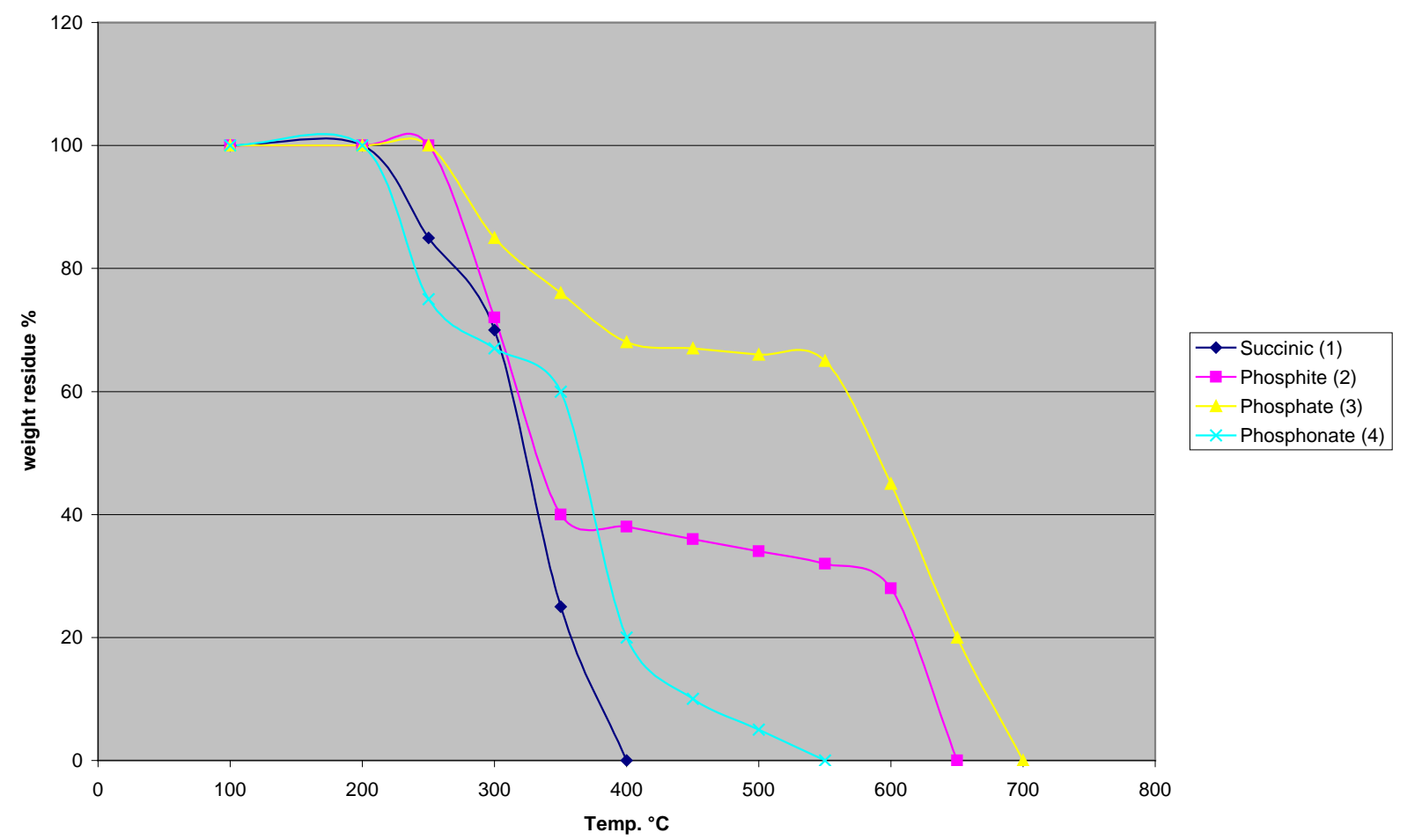

Figure 6. TGA of the linear Polyesters: Succinic acid (1), Polyphosphite (2), Polyphosphate (3) and Polyphosphonate (4), air, $5 \mathrm{~K} / \mathrm{min}$.

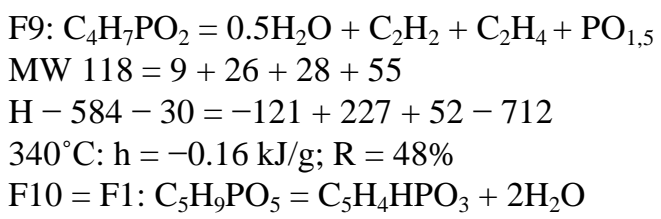

Intumescence $350^{\circ} \mathrm{C}: \mathrm{h}=-0.01 \mathrm{~kJ} / \mathrm{g} ; \mathrm{R}=\mathbf{4 0 \%}$

$\mathrm{F} 11=\mathrm{F} 2 \mathrm{C}_{5} \mathrm{H}_{4} \mathrm{HPO}_{3}=\mathrm{CH}_{4}+0.5 \mathrm{H}_{2} \mathrm{O}+\mathrm{C}_{4} \mathrm{PO}_{2,5}$

$\mathrm{F} 9+\mathrm{F} 10+\mathrm{F} 11: \mathrm{C}_{9} \mathrm{H}_{16} \mathrm{O}_{7} \mathrm{P}_{2}=3 \mathrm{H}_{2} \mathrm{O}+\mathrm{CH}_{4}+\mathrm{C}_{2} \mathrm{H}_{2}+\mathrm{C}_{2} \mathrm{H}_{4}+\mathrm{PO}_{1,5}+\mathrm{C}_{4} \mathrm{PO}_{2,5} \mathrm{~h}=-0.28 \mathrm{~kJ} / \mathrm{g} ; \mathrm{R}=40 \%$

MW $298=54+16+26+28+55+119$

$\mathrm{H}-2113+83=-726-121+227+52-712-750$

Phosphate-polyester (3) with repetition unite $\mathrm{C}_{9} \mathrm{H}_{16} \mathrm{O}_{9} \mathrm{P}_{2}(\mathrm{MW}=330 \mathrm{~g} / \mathrm{mole}) ; \mathbf{R}_{5000^{\circ} \mathrm{C}}=68.5 \% ; \mathrm{h}=-0.21$ $\mathbf{k J} / \mathbf{g}$

$250^{\circ} \mathrm{C}: \mathrm{h}=-0.5 \mathrm{~kJ} / \mathrm{g} ; \mathrm{R}=100 \%$

F12: $\mathrm{C}_{9} \mathrm{H}_{16} \mathrm{O}_{9} \mathrm{P}_{2}=\mathrm{C}_{5} \mathrm{H}_{9} \mathrm{PO}_{5}+\mathrm{C}_{4} \mathrm{H}_{7} \mathrm{PO}_{4}$

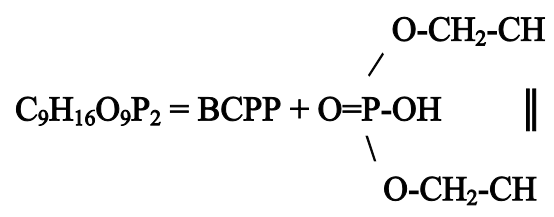

MW $330=180+150$

$\mathrm{H}-2548+165=-1380-1003$

$350^{\circ} \mathrm{C}: \mathrm{h}=0.12 \mathrm{~kJ} / \mathrm{g} ; \mathrm{R}=94.5 \%$

F13: $\mathrm{C}_{4} \mathrm{H}_{7} \mathrm{PO}_{4}=\mathrm{C}_{4} \mathrm{H}_{4} \cdot \mathrm{HPO}_{3}+\mathrm{H}_{2} \mathrm{O}$

MW $150=132+18$

$\mathrm{H}-1003+41=-720-242$

Intumescence $350^{\circ} \mathrm{C}: \mathbf{h}=-\mathbf{0 . 3 2} \mathbf{k J} / \mathbf{g} ; \mathbf{R}=\mathbf{8 7 \%}$

F14: $\mathrm{C}_{4} \mathrm{H}_{4} \cdot \mathrm{HPO}_{3}=\mathrm{CH}_{4}+0.5 \mathrm{H}_{2} \mathrm{O}+\mathrm{C}_{3} \mathrm{PO}_{2,5}$ 

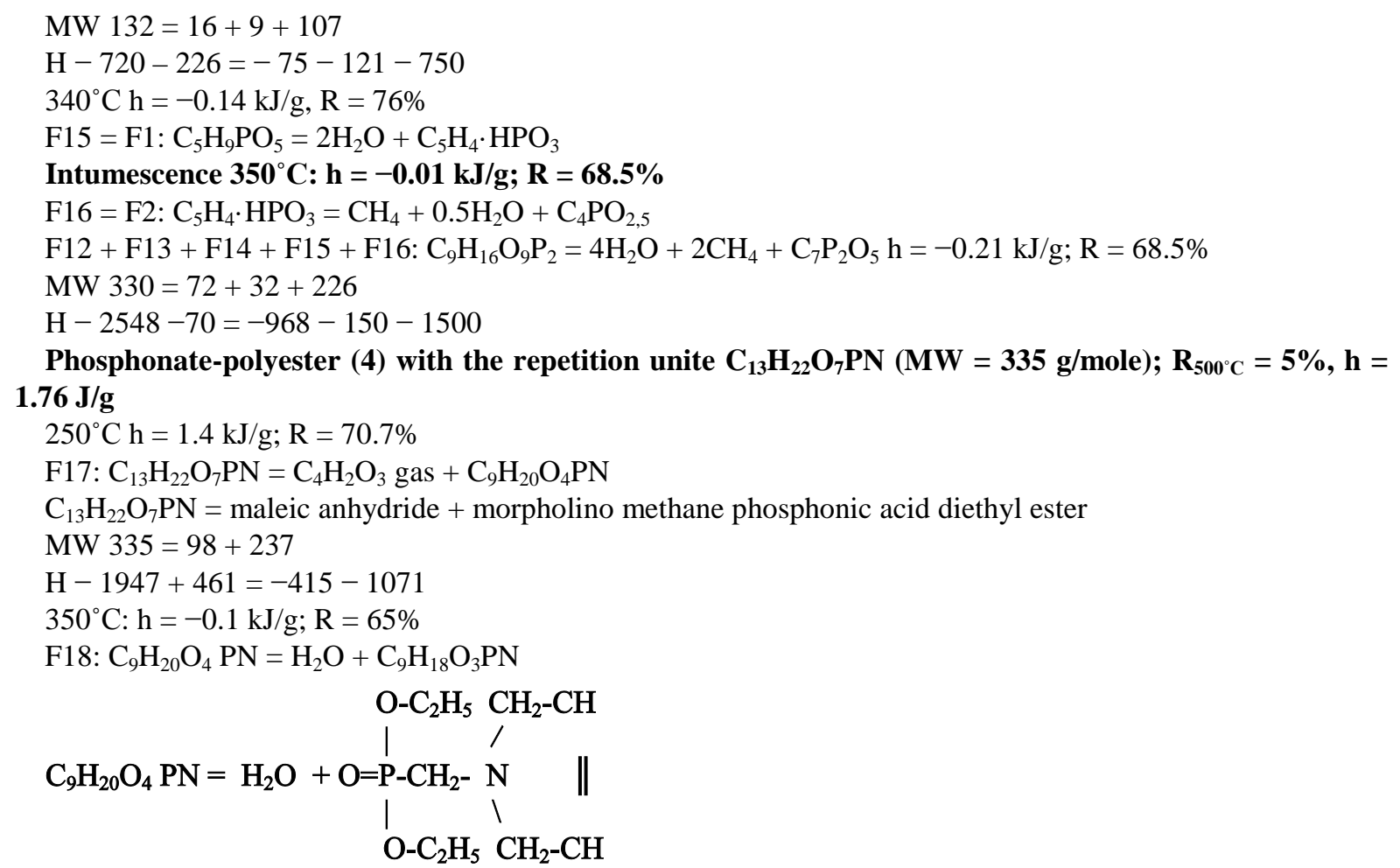

MW $237=18+219$

$\mathrm{H}-1071-33=-242-862$

$355^{\circ} \mathrm{C}: \mathrm{h}=0.28 \mathrm{~kJ} / \mathrm{g} ; \mathrm{R}=0 \%$

F19: $\mathrm{C}_{9} \mathrm{H}_{18} \mathrm{O}_{3} \mathrm{PN}=\mathrm{CH}_{2} \mathrm{O}+2 \mathrm{C}_{4} \mathrm{H}_{6}+\mathrm{NH}_{3}+0.5 \mathrm{H}_{2} \mathrm{O}+\mathrm{PO}_{1,5}$

$\mathrm{MW} 219=30+2 \times 54+17+9+55 \mathrm{H}-796+94=-116+2 \times 146.5-46-121-712$

$\mathrm{F} 17+\mathrm{F} 18+\mathrm{F} 19: \mathrm{C}_{13} \mathrm{H}_{22} \mathrm{O}_{7} \mathrm{PN}=1.5 \mathrm{H}_{2} \mathrm{O}+\mathrm{PO}_{1,5}+2 \mathrm{C}_{4} \mathrm{H}_{6}+\mathrm{NH}_{3}+\mathrm{C}_{4} \mathrm{H}_{2} \mathrm{O}_{3}+\mathrm{CH}_{2} \mathrm{O} \mathrm{h}=1.76 \mathrm{~kJ} / \mathrm{g} ; \mathrm{R}=0 \%$

$\mathrm{MW} 335=27+55+2 \times 54+17+98+30$

$\mathrm{H}-1947+588=-363-712+2 \times 146.5-46-415-116$

The intumescent Phosphite-Polyester (2) and the Phosphate-Polyester (3) degraded to the same intumescent product BCPP. They developed exotherm heats of decomposition and the residues at $500{ }^{\circ} \mathrm{C}$ amounted to $40 \%$ and 68\%. The nonintumescent Succinic-Polyester (1) and Phosphonic-Polyester (4) degraded under endotherm heat uptake and their residues at $500^{\circ} \mathrm{C}$ amounted to $0 \%$.

\subsection{Powder Coating Manufacturing Process}

In Table 2 the formulations for intumescent powder coatings were summarized: In order to be comparable, all recipes comprised the same amount of titanium dioxide, which reacted with phosphorous pentoxide to titanium pyrophosphate. Recipe No.1 comprised thermoplastic plastisized polyvinylchloride PPVC, titanium dioxide $\mathrm{TiO}_{2}$, ammonium polyphosphate APP and the intumescent additive bicyclopentaerythritol phosphate BCPP.

In recipe No. 2 polypropylene PP plus peroxide degraded to a well flowing binder. $\mathrm{TiO}_{2}$, APP and BCCP were added. Recipe No. 3 comprised the linear polyester (1), uretdione and BCPP as intumescent additive as well as titanium dioxide and ammonium polyphosphate.

In Recipe No. 4 the intumescent polyesters (2) reacted with uretdione to polyurethane in the presence of $\mathrm{TiO}_{2}$. Recipe No. 5 comprised the intumescent polyester (3) uretdione and $\mathrm{TiO}_{2}$. As the polyester (4) was not intumescent, in recipe No. 6 in addition to uretdione, $\mathrm{TiO}_{2}$, APP the intumescent compound BCPP was added. In recipe No. 7 use was made of the intumescent mixture polyethylene glycol with ammonium polyphosphate.

All formulations were manufactured by the dry blending process. The obtained fine powders were classified by sieving. The particle size distributions were measured on a Master Sizer XSB.OD (Malvern Instrument). The white powders with particles between 30 and $150 \mu \mathrm{m}$ showed the characteristic data of Table 3 . 
Table 2. Formulations of intumescent powder coatings.

\begin{tabular}{|c|c|c|c|c|c|c|c|}
\hline No & 1 & 2 & 3 & 4 & 5 & 6 & 7 \\
\hline Binder 1 & 70 PPVC & 69.7 PP & $\begin{array}{c}48.7 \\
\text { Polyester1 }\end{array}$ & $\begin{array}{c}50.8 \\
\text { Polyester2 }\end{array}$ & $\begin{array}{c}47.8 \\
\text { Polyester3 }\end{array}$ & $\begin{array}{c}41.8 \\
\text { Polyester4 }\end{array}$ & 36 PEG \\
\hline Binder 2 & & & $\begin{array}{c}21.6 \\
\text { Uretdione }\end{array}$ & 45 Uretdione & 48 Uretdione & 29 Uretdione & 17 Uretdione \\
\hline $\mathrm{TiO}_{2}$ & 4 & 4 & 4 & 4 & 4 & 4 & 4 \\
\hline APP & 11.5 & 11.5 & 11.5 & & & 11,5 & 41 \\
\hline ВСРР & 13.5 & 13.5 & 13.5 & & & 13,5 & \\
\hline Auxiliary 1 & 1 Castearate & 1 Castearate & 0.1 Dabco & 0.1 Dabco & 0.1 Dabco & 0.1 Dabco & 1.7 Zeolithe \\
\hline Auxiliary 2 & & 0.3 Peroxide & 0.1 Snoct. & 0.1 Snoct. & 0.1 Snoct. & 0.1 Snoct & 0.2 Silicone \\
\hline Auxiliary 3 & & & $\begin{array}{l}0.5 \text { Montan } \\
\text { wax }\end{array}$ & & & & $0.1 \mathrm{DBTDL}$ \\
\hline
\end{tabular}

Table 3. Characteristic data of the powders.

\begin{tabular}{|c|c|c|c|c|c|c|c|}
\hline No & 1 & 2 & 3 & 4 & 5 & 6 & 7 \\
\hline Tglass $\left({ }^{\circ} \mathrm{C}\right)$ & 70 & 150 & 65 & 90 & 80 & 95 & 55 \\
\hline bulk density $\left(\mathrm{g} / \mathrm{cm}^{3}\right)$ & 0.65 & 0.7 & 0.65 & 0.6 & 0.7 & 0.65 & 0.8 \\
\hline viscosity $175^{\circ} \mathrm{C}$ (Pas) & 650 & 250 & 160 & 10 & 15 & 30 & 100 \\
\hline Tfusion $\left({ }^{\circ} \mathrm{C}\right)$ & 140 & 165 & 180 & 190 & 200 & 170 & 140 \\
\hline cure time $\left(\mathrm{min} /{ }^{\circ} \mathrm{C}\right)$ & $15 / 250$ & $15 / 240$ & $10 / 200$ & $10 / 210$ & $10 / 210$ & $10 / 200$ & $10 / 160$ \\
\hline film density $\left(\mathrm{g} / \mathrm{cm}^{3}\right)$ & 1.5 & 1.4 & 1.45 & 1.05 & 1.05 & 1.45 & 1.55 \\
\hline apply (g) (d = $0.5 \mathrm{~mm})$ & 21 & 22.5 & 21.5 & 30 & 30 & 21.5 & 20 \\
\hline
\end{tabular}

In Figure 7 the melt viscosities at low shear forces $230 \mathrm{sec}^{-1}$ were measured in dependence of the temperature in a Rheograph 2000 for the thermoplastic formulations PPVC No. 1 and PP No. 2 according DIN 54811.

The curing of thermosets No. 3-7 was investigated on a plasticorder. The results for the formulations No. 3 with polyester (1), No. 4 with the phosphite polyester (2), No. 5 with the phosphate polyester (3), No. 6 with the phosphonate polyester (4) and No. 7 with the 1/1 mixture polyethylene glycol PEG and ammonium polyphosphate APP were plotted in Figure 8. At time 0 the product temperature was $100^{\circ} \mathrm{C}$ and the heating rate was $5 \mathrm{~K} / \mathrm{min}$. After 20 minutes $200^{\circ} \mathrm{C}$ was reached and further heating was stopped.

In comparison with the viscosities of thermoplastic formulations the viscosity minima of thermosets were lower, which was also manifested by a smoother surface of the obtained films.

Due the lower particle volume concentrations the films of the intrinsic intumescent powder coatings No.4 and No.5 showed more gloss.

\subsection{Spraying}

The electrically loaded powders were sprayed on preheated and grounded steel panels. The film thicknesses varied between 0.88 and $1.2 \mathrm{~mm}$ according the applies given in Table 3 .

\subsection{Curing and Melting}

The curing temperatures with $250^{\circ} \mathrm{C}$ at most were below the required temperature of intumescence of $275^{\circ} \mathrm{C}$ and $350^{\circ} \mathrm{C}$. The coatings on the panels showed film thicknesses of about $500 \mu \mathrm{m}$ in average.

\subsection{Fire Test}

The coated panels with a horizontal perimeter to area factor $\mathrm{Hp} / \mathrm{A}=400 \mathrm{~m}^{-1}$ were equipped with two thermocouples, each for continuous measurements of temperature. The measured data were averaged out.

In Figure 9 a picture showing the front side of the furnace was taken, when the burning test had been finished. 


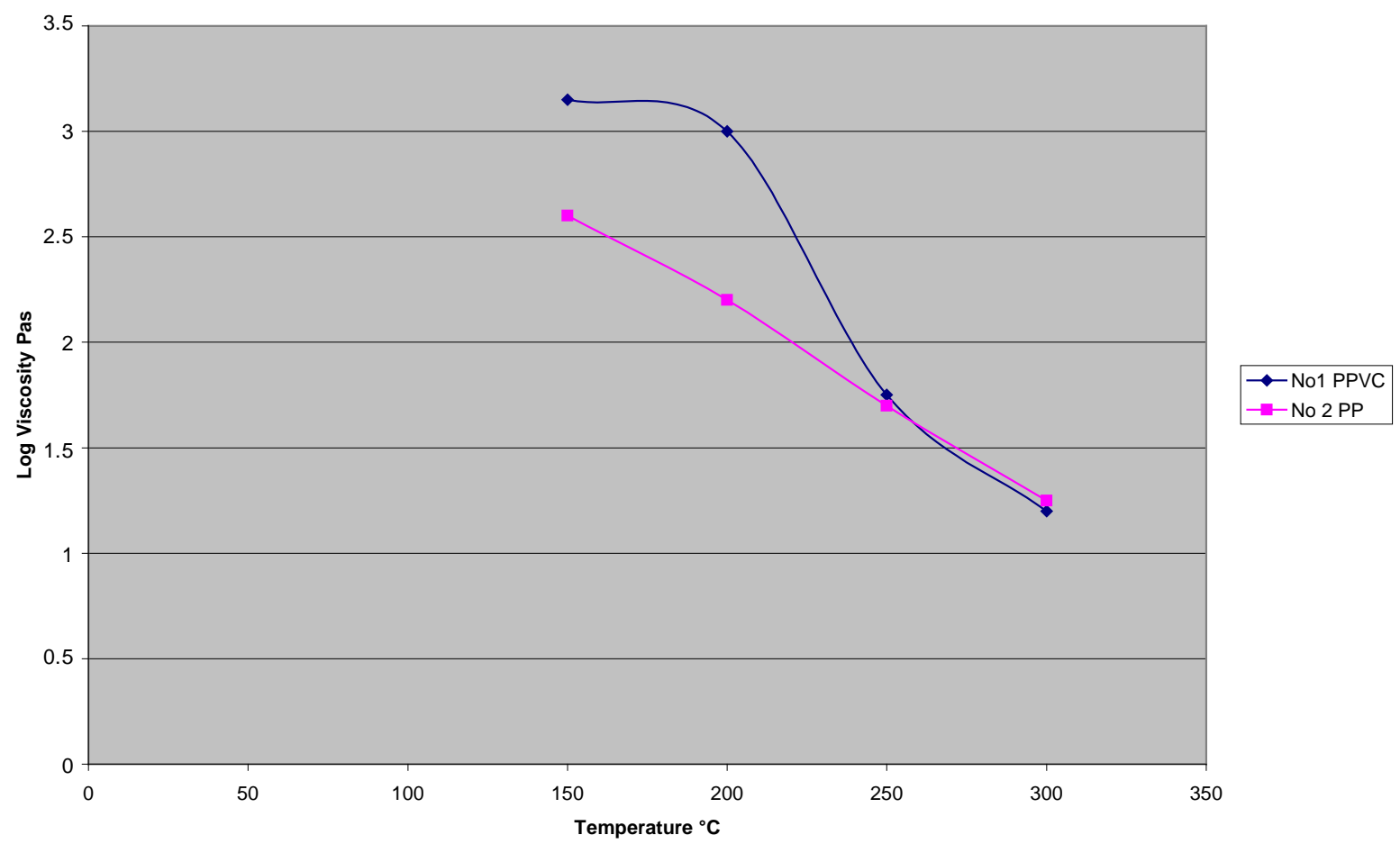

Figure 7. Viscosity as a function of temperature for the thermoplastics No. 1 PPVC and No. 2 PP.

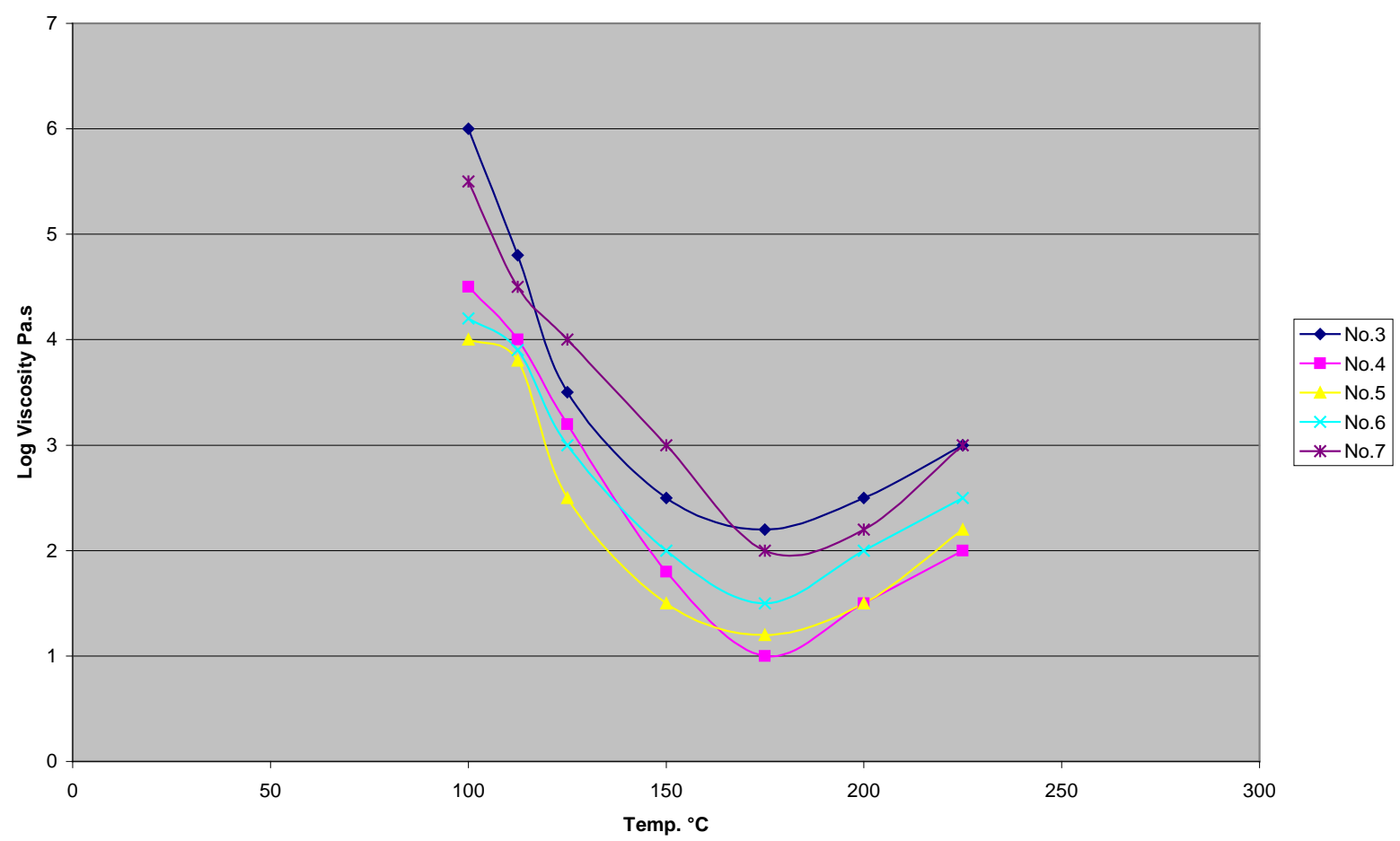

Figure 8. Viscosity as a function of temperature, heating rate $5 \mathrm{~K} / \mathrm{min}$ starting from $100^{\circ} \mathrm{C}$ for the thermosets No. 3 , No. 4 , No. 5 , No. 6 and No. 7.

In Figure 10 the temperatures of the uncoated panel as well as those of the panels protected by the different powder coatings and by the commercial water borne varnish Nonfire S168 were recorded in dependence of time. The efficiency was measured by the time lag until $500^{\circ} \mathrm{C}$ were reached. Under this aspect following ranking was 


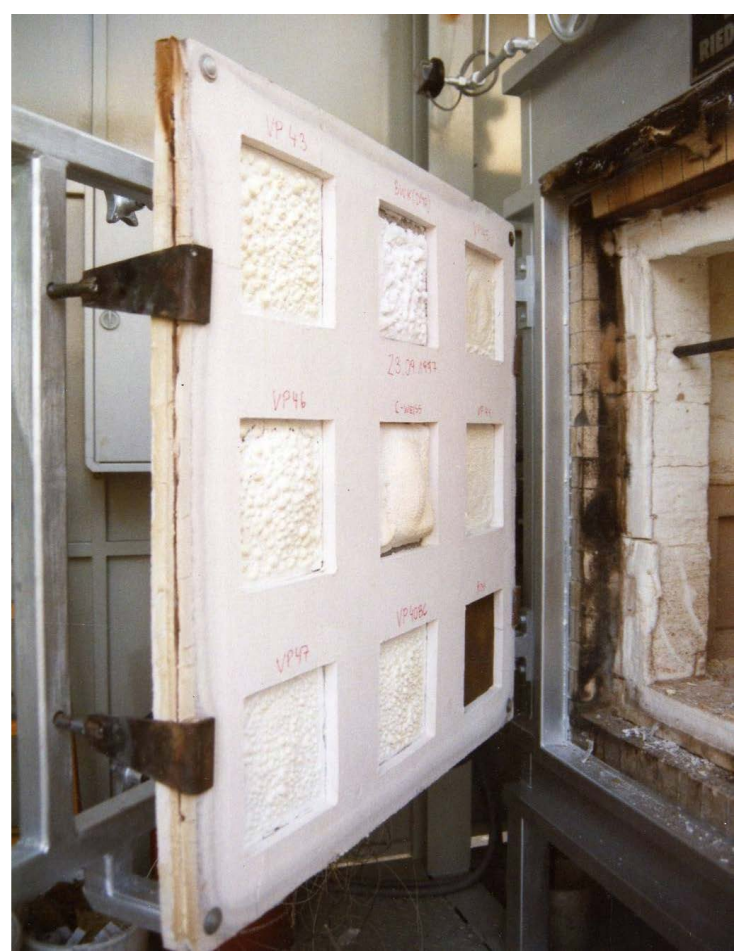

Figure 9. The front side after the burning test showing the 7 samples No. 1 , No. 2, No. 3, No. 4, No. 5, No. 6, No. 7, the uncoated panel and the reference panel Nonfire S168.

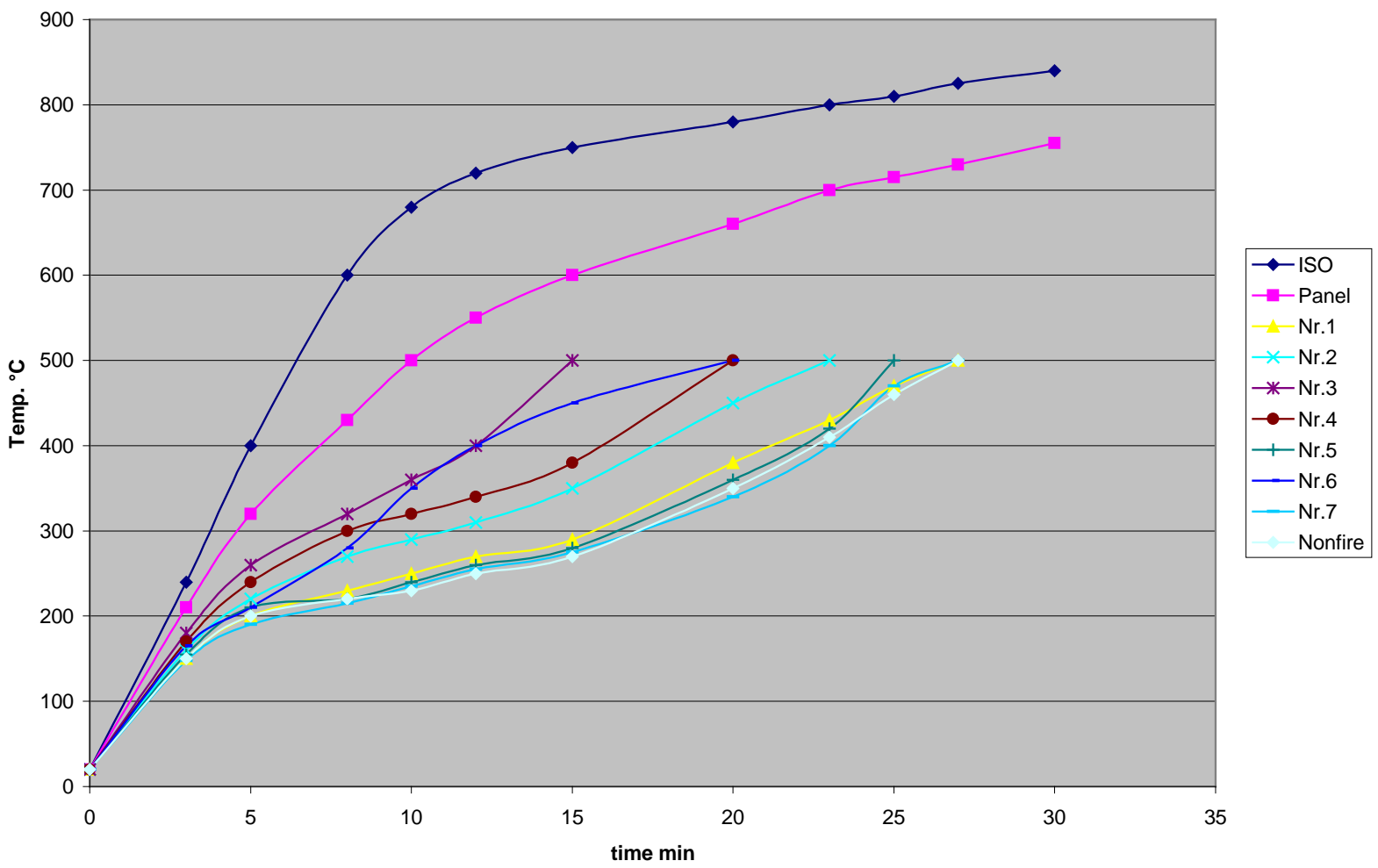

Figure 10. Fire test: temperatures versus time for the furnace, for the uncoated panel with a perimeter to $\mathrm{area} \mathrm{Hp} / \mathrm{A}=400$ $\mathrm{m}^{-1}$, for the seven powder coated panels and for the reference panel coated with the water borne varnish Nonfire S168 all at $0.5 \mathrm{~mm}$ film thickness. 
achieved in Table 3: the PPVC plus BCPP (No. 1) and PUR with PEG/APP (No. 7) were the favourites and were more or less equal in efficiency with the reference coating Nonfire S168.

In Table 4 the time lags until $500^{\circ} \mathrm{C}$ were reached, the film thickness after expansion $\mathrm{df}$ and the expansion factor EF as well as the amount of inorganic compounds were recorded.

Nonfire S168 had the highest film density and the highest expansion followed by PPVC (No. 1) and PEG/ Uretdione (No. 7).

\section{Discussion}

The temperature differences $\mathrm{dT}_{1}$ between the temperature curve of the furnace and that of the naked $5 \mathrm{~mm}$ panel served for the calculation of the heat flux per area $\mathrm{Q} / \mathrm{F}$ according to Equation (4).

$$
\mathrm{Q} / \mathrm{F}=\mathrm{dT}_{1} /(1 / \mathrm{a}+\mathrm{Do} / \mathrm{lambda})=150 /(0.3333+0.1666)=150 / 0.5=300 \mathrm{~W} / \mathrm{m}^{2}
$$

In Equation (4) the temperature difference $\mathrm{dT}_{1}=150^{\circ} \mathrm{C}$, the heat transmission number for free air convection $\mathrm{a}=3 \mathrm{~W} /\left(\mathrm{m}^{2} * \mathrm{~K}\right)$, the thickness of the panel $\mathrm{Do}=0.005 \mathrm{~m}$ and the heat conductivity of air lambda $=0.03 \mathrm{~W} /(\mathrm{m} * \mathrm{~K})$ were introduced. A heat flux per area of $300 \mathrm{~W} / \mathrm{m}^{2}$ was calculated, which was used in order to estimate the temperature difference between the naked and the coated panel $\mathrm{dT}_{2}[14]$.

The difference in temperature between the naked panel and the coated panel $\mathrm{dT}_{2}$ was calculated in Equation (5).

$$
\mathrm{dT}_{2}=\mathrm{Q} / \mathrm{F} \times\left(1 / \mathrm{a}+\mathrm{d} \times(\mathrm{EF})^{2} /\left(3 \times \mathrm{lambda}_{\mathrm{f}}\right)=300 \times\left[1 / 3+0.0005 \times 27^{2} /(3 \times 1)\right]=135^{\circ} \mathrm{C}\right.
$$

In Equation (5) the film thickness of the coating $d$ was $0.0005 \mathrm{~m}$ and the expansion factor $E F=27$. The heat conductivity of the unexpanded film lambda ${ }_{\mathrm{f}}$ amounted to $1 \mathrm{~W} /\left(\mathrm{m}^{2} * \mathrm{~K}\right)$.

In Figure 10 a temperature difference between uncoated and coated panel of about $150^{\circ} \mathrm{C}$ was observed. In principle Equations (4) and (5) described correctly the results and predicted the task for further improvements by increasing the expansion factor and reducing the heat conductivity.

The fire tests showed that the efficiency of the powder coating was increased by a highly expanded but stable char with low thermal conductivity. A low temperature of intumescence was of advantage. Formulation No. 7 based on PEG/APP reacted under intumescence at $275^{\circ} \mathrm{C}$ and cured at $160^{\circ} \mathrm{C}$, but the low temperature of fusion caused difficulties in the manufacturing process. The other extreme was formulation No. 1 based on PPVC with $350^{\circ} \mathrm{C}$ temperature of intumescence and $250^{\circ} \mathrm{C}$ temperature of curing. High degree of fillers caused unsmooth surfaces in every case. Therefore the formulations based on intumescent polyesters with No. 4 and No. 5 had a higher potential of further improvement, because they offered the possibility of additional dosage of fillers or ingredients.

\section{Conclusions}

The screening of seven very different formulations indicates the possibility of manufacturing and applying intumescent powder coatings based on thermoplastic as well as thermoset non-cross linked binders. Intumescence is realized by the addition of the intumescent ingredient BCPP, by intumescent polyesters comprising phosphate or phosphite groups and by the mixture of PEG/APP. In every case intumescence follows the common reaction in Equation (6).

$$
\mathrm{C}_{\mathrm{n}} \mathrm{H}_{\mathrm{m}} \mathrm{HPO}_{3}=(\mathrm{m} / 4) \times \mathrm{CH}_{4}+(\mathrm{n}-\mathrm{m} / 4) \times \mathrm{C} 0.5 \mathrm{P}_{2} \mathrm{O}_{5}+0.5 \mathrm{H}_{2} \mathrm{O}
$$

\begin{tabular}{|c|c|c|c|c|c|c|c|c|}
\hline No & 1 & 2 & 3 & 4 & 5 & 6 & 7 & Nonfire S168 \\
\hline time (min) & 27 & 24 & 15 & 20 & 25 & 20 & 27 & 27 \\
\hline Expansion factor $E F=(d f / d-1)$ & 19 & 17 & 11 & 14 & 15 & 19 & 29 & 35 \\
\hline Expanded film thickness df (mm) & 10 & 9 & 6 & 7.5 & 8 & 10 & 15 & 18 \\
\hline film density $\left(\mathrm{g} / \mathrm{cm}^{3}\right)$ & 1.5 & 1.4 & 1.45 & 1.05 & 1.05 & 1.45 & 1.55 & 1.6 \\
\hline Inorganic compounds (\%) & 15.5 & 15.5 & 15.5 & 4 & 4 & 15.5 & 46.7 & 35 \\
\hline
\end{tabular}

Table 4. Performance in fire test: time, until $500^{\circ} \mathrm{C}$ were reached, expansion factor EF, expanded film thickness df, film density and amount of inorganic compounds. 
In a comparative fire test, the powder coating based on the thermoplastic binder PPVC No. 1 as well as that based on the polyurethane thermoset binder No. 7 are comparative in efficiency with commercial water borne coating No. 8 Nonfire S168 at the same film thickness of $0.5 \mathrm{~mm}$.

Nevertheless the restriction remains that the film thickness of powder coatings can not be increased to any high value wished. A higher potential of further improvements is granted to formulations based on intumescent polyesters No. 4 and No. 5, because their low amount of fillers allows the further addition of performance improving ingredients.

Among intumescence, intumescent powder coatings have to fulfil several demands as strong adhesion to the substrate, flexibility and hardness in the right balance. They have to resist humidity and sun shine, tested by the Salt Spray test and the Florida test. The present results and the advantages of powder coatings as well as the circumstance that powder coating are not restricted to steel protection alone will encourage further work. In a future vision building parts, such as columns and pipes, coated by intumescent powder coatings could be continuously manufactured in such a way that the still hot cast or moulded specimens are sprayed in a one step process.

\section{References}

[1] Herr, C. (2007) Equipment Considerations When Converting to a Compliant Coating. Metal Finishing, 40-43.

[2] Othmer, K. (1982) Encyclopedia of Chemical Technology. 3rd Edition, Vol. 19, Powder Coatings, 1-26.

[3] Othmer, K. (2007) Encyclopedia of Chemical Technology. 5th Edition, Vol. 7, Coating Process, 1-34, Powder, 35-67, Coating Process Spray, 68-76, Coating, 77-95.

[4] Horacek, H. (2005) Intumeszierende Pulverbeschichtung. EP 1659157 A1.

[5] Leigh and Co. (2002) Coating Composition. WO 02096996 A1.

[6] Chance and Hunt Lim., Ferro Lim. (2002) Fire Retardant Intumescent Coating. WO 0277110 A1.

[7] Leigh and Co. (2003) Radiation Curable Intumescent Coatings. WO 03066749 A1.

[8] Rohm and Haas (2005) Intumeszierende Pulverzusammensetzung und Daraus Hergestellte Beschichtungen. EP 168368384 A1.

[9] Piazza, D., Silveira, D.S., Lorandi, N.P., Birriel, E.J., Scienza, L.C. and Zattera, A.J. (2012) Polyester Based Coatings with Montmorillonite Nanoparticles Applied on Carbon Steel. Progress Inorganic Coatings, 78, 42-46.

[10] Horacek, H. (2009) Reactions of Stoichiometric Paints. Journal of Applied Polymer Science, 113, 1745-1756. http://dx.doi.org/10.1002/app.29940

[11] Zobel, L. (2005) Enviral and Meeh, mo Metalloberfläche Jg.59 “Pulverbeschichtungen”. 12-14. www.mo-oberflaeche.de

[12] Lucas, H.J., Mitchell Jr., F.W. and Scully C.N. (1950) Cyclic Phosphites of Some Aliphatic Glycols. Journal of the American Chemical Society, 72, 5491-5495. http://dx.doi.org/10.1021/ja01168a032

[13] Rätz, R. and Sweeting, O.J. (1963) Some Chemical Reactions of 3,9-Dichloro-2,4,8,10-tetraoxa-3,9-diphosphaspiro [5.5] Undecane 3,9-Dioxide. The Journal of Organic Chemistry, 28, 1608-1912. http://dx.doi.org/10.1021/j001041a043

[14] Horacek, H. and Pieh, St. (2000) The Importance of Intumescent Systems for Fire Protection of Plastic Materials. Polymer International, 49, 1106-1114. http://dx.doi.org/10.1002/1097-0126(200010)49:10<1106::AID-PI539>3.0.CO;2-I 